This is the accepted manuscript of Bernard, S., \& Nicolau, J. L. (2022). Environmental certification and hotel market value. International Journal of Hospitality Management, 101,

103129.

\title{
ENVIRONMENTAL CERTIFICATION AND HOTEL MARKET VALUE
}

\section{INTRODUCTION}

In contrast to oil, utility, and chemical companies, the hotel industry has not been traditionally labeled as a high-polluting industry; however, this view has changed over the years due to increased pressure from various stakeholder groups (e.g., the public, customers, regulators, and non-governmental organizations) (Chan \& Wong, 2006). Indeed, Tolkach (2021) recently propose that sustainability scholars adopt a skeptical and critical mindset that challenges already-dominant narratives of conspicuous consumption in tourism. This approach will promote more radical alternatives that will effectively reduce the industry's impact on climate change. Accordingly, there is an ongoing research interest in estimating the environmental impact of the hotel industry as illustrated by the extensive amount of waste it generates and energy it consumes (Bohdanowicz, 2005; Bojanic \& Warnick, 2020; Gupta, Dash, \& Mishra, 2019; Lesar et al., 2020). For example, hotels consume up to $70 \%$ of their energy on heating, ventilation, and air conditioning (HVAC) operations (Goldstein \& Primlani, 2012), and the average water use per guest night as discovered in Moroccan (Hadjikakou et al., 2013) and Spanish (Tirado et al., 2019) locations ranges from 208 to 594 liters.

To counter these environmental impacts, some hotel operators have publicly self-declared their commitment to various environmental management initiatives (Lee, Hsu, Han, \& Kim, 2008; Jauhari \& Manaktola, 2007), while at the same time avoiding incurring the high operational costs to tangibly carry out their obligations (Stefan \& Paul, 2008).

Since the global nature of the hospitality and tourism industry makes it difficult to regulate hotels' environmental commitments (de Grosbois, 2012), some hotel properties have been accused of "greenwashing" and promoting the perception of being ecofriendly while not implementing appropriate measures to that end (Chen, Bernard, \& Rahman, 2019; Rahman, Park, \& Chi, 2015). Consequently, not all hotels' ecofriendly claims are perceived as authentic and are often viewed with suspicion (Smith \& Font, 2014). The proliferation of such skepticism toward the hotel industry can incur financial and reputational risks (Mensah \& Blankson, 2014) and create confusion in the marketplace, with customers/investors unable to distinguish between deceitful and non-deceitful environmental claims made by hotels. As a result, some progressive hotels have adopted various environmental awards (also known as "green awards", "environmental certification", or "ecolabels") to distinguish themselves from hotels that greenwash to improve the perception of their environmental performance (Karlsson \& Dolnicar, 2016). Expectedly, some leading hotel chains, including Choice Hotels, Marriott International, Hilton, Hyatt, and Wyndham Hotels \& Resorts, have announced their accumulation of various environmental awards to signal their commitment to reduce their carbon footprint and enhance their ecological credentials.

While several studies have examined the relationship between environmental awards and financial performance in hotels (Chong \& Verma, 2013; Claver-Cortés et al., 2010; Peiró-Signes et al., 2014), they focus primarily on backward-looking key performance metrics (e.g., gross

operating profit per available room, booking revenue, return on asset, occupancy, etc.) following ISO 14001 certification. However, these studies have overlooked forward-looking metrics, such 
as market value (expressed as the share price times the number of shares), to provide an objective measure of the impact of environmental awards on hotel financial performance (Fama, 1991). It is essential to take a legitimacy approach, particularly for chain hotels, who not only benefit economically from using fewer resources, but can also increase their visibility and improve their corporate images via environmental engagement (Bonilla Priego et al., 2011). In this context, a high level of environmental accountability is placed on hotels, particularly by external stakeholders, who expect hotels to not only implement environmental initiatives to ameliorate their impact on the environment, but also yield economic returns (Tsai et al., 2010). Furthermore, since implementing environmental awards is a long-term environmental strategy, a long-term measurement, such as market value, is recommended. However, no empirical hospitality studies as of yet link environmental awards to market value.

In particular, the present research is a response to a review study by Sharma, Chen, and Liu (2020) on eco-innovation in hospitality research. The authors suggest that scholars measure the effectiveness of environmental awards in generating green behavior and minimizing greenwashing concerns. Specifically, they call for more objective measures of the effect of environmental awards on green behavior. Considering these gaps in the extant research, this study empirically tests the effect of environmental awards on market value for the top U.S. chain hotels from 1996 to 2020. Chain hotels were chosen due to their global reach and the increasing importance of sustainable development strategies particularly among large-scale hotels, whose use of resources considerably tax the environment (Rico et al., 2020). To fulfill this research objective, this study applies an event study methodology and uses the Factiva database to detect all announcements of environmental awards made by the major publicly traded hotels in the U.S. stock market. The results reveal that the stock market rewards hotels that aim to reduce negative environmental impacts, with a significantly high impact of first-time awards and a U-shaped effect of subsequent awards.

By analyzing the effect of environmental certifications granted by third-party entities on a forward-looking performance metric such as the market value of hotels, this study contributes to theory by going beyond the "cost to be green - pay to be green" theoretical framework and adding several explanatory dimensions to enhance our finding of a positive effect of environmental awards on the market value of hotels. It expands the current environment management literature by proposing and testing the effects of several industry-specific first-time and cumulative environmental awards. Regarding practical contributions, the insights gained from the findings provide hotel managers with valuable insights to further improve environment management systems that prioritize environmental awards.

The remainder of this study reviews relevant literature related to environmental management, specifically within the limits of environmental awards, and their effect on firm performance. The next section is followed by a detailed description of our data collection processes and research methods. Finally, the study concludes with a discussion of theoretical and practical implications and important future research directions.

\section{ENVIRONMENTAL AWARDS IN A HOTEL CONTEXT}

Environmental awards range from self-proclaimed to verified and are typically awarded by third-party firms (Global Ecolabelling Network, 2004). The goal of certification is "to encourage the demand for and supply of those products and services that cause less stress on the environment, thereby stimulating the potential for market-driven continuous environmental improvement” (Global Ecolabelling Network, 2004, p.1). Thus, the literature increasingly 
recognizes environmental awards as a type of social legitimacy action for three reasons (Geerts, 2014; Parguel, Benoit-Moreau, \& Larceneux, 2011).

First, environmental certifications signal the voluntary implementation of environmental initiatives by hospitality providers, thus giving credibility through conformity assessments that a hotel has taken concrete action toward its environmental commitment (Geerts, 2014). In fact, implementing environmental awards can simplify default options for eco-conscious guests that are often accused of hypocrisy (Sun et al., 2020) by integrating practices that benefit the environment in the service design. Supporting this view, Dolnicar (2020) propose designing for environmental sustainability such that social norms can be leveraged in such a way that makes it difficult for tourists to choose options that are contrary to their beliefs.

Second, given that information asymmetry concerns are peculiar to service industries due to the inseparability of product and service at the point of consumption (Rocha \& Fink, 2017), environmental awards can assure the public that a hotel is committed to reducing environmental harm, since certified properties are also awarded with identifiable logos (Geerts, 2014); however, an added complexity is that there are over 458 environmental awards globally (ecolabelindex.com), with over 100 offerings specific to hospitality and tourism businesses (Bratt et al., 2011). This has raised concerns that the large volume of awards will become less recognizable and less trusted by consumers (Buckley, 2001) since they have dissimilar meanings, messages, criteria, and geographical scopes (Bratt et al., 2011). Thus, in line with our study objectives, filtering the effect of environmental awards utilized by top chain hotels can further refine the list of awards that are acknowledged by the public.

Third, environmental awards offer an opportunity to increase the profitability of membercertified hotels. On one hand, environmental engagement can improve internal and human operational efficiencies due to increased production processes while simultaneously reducing resource consumption and production costs (Yusoff et al., 2020). On the other hand, environmental engagements produce external benefits including increasing stakeholder investment (Chan, 2021), improving hotels' environmental image to create a competitive advantage (Chen \& Chang, 2013), and increasing share price value (Mycoo, 2006; Nicolau, 2008). Following the latter view outlining externally driven benefits, the present study builds on the current literature to assess the influence of environmental awards on hotel market value.

Due to its global reach, the hotel sector provides a fertile context to advance research on the effect of environmental awards on market value. First, chain hotels can create strategic alliances in several destinations simultaneously due to their standardization characteristics, which permit them to rapidly infiltrate local markets in countries where environmental award standards already exist (Ertuna et al., 2019). Second, unlike governmental regulations that impose external requirements on firms, a hotel manager's decision to implement environmental activities arises from within the firm and constitutes a voluntary, self-regulatory structure (de Grosbois, 2012). This unconventional environmental strategy is a shift from the dominant approach to first comply with regulatory or legal requirements (reactive) and then subsequently and gradually increase voluntary environmental practices (proactive) (Garcés-Ayerbe et al., 2016; Murillo-Luna et al., 2008). Accordingly, this proactive approach can minimize the market's skepticism toward hotel companies' environmental initiatives since it signals that a commitment truly is being made to implement actions to reduce environmental impact (Karlsson \& Dolnicar, 2016).

\section{THE IMPACT OF ENVIRONMENTAL MANAGEMENT ON HOTEL PERFORMANCE}


Environmental management is the practice of "embracing both technical and organizational activities aimed at reducing the negative environmental impact caused by a firm's operations" (Gil et al., 2002, p. 458). Accordingly, environmental awards constitute the most widely used environmental management strategy (Segarra-Oña et al., 2012), thus enabling a broad range of internal and external benefits for hotels, including enhanced reputation, increased profitability, a more positive image, and competitive advantage through differentiation (Chen \& Chang, 2013; Leonidou et al., 2013; Cavero-Rubio et al., 2020). Nevertheless, implementing environmental awards can be costly (Ham \& Lee, 2011), and are often difficult to measure due to intangible outcomes such as reputation and image (Kang et al., 2012). Considering these complexities, Myung et al. (2020) categorizes a firm's economic performance based on accounting performance, hotel-specific performance, and market performance. Accounting performance evaluates managers' discretion regarding allocating environmental resources and hotel-specific performance is the quantification of operational processes such as revenue per available room, and available daily rate, while market performance considers the external market's reaction to organizational actions (Myung et al., 2020).

A thorough review of literature finds that environmental management activities (including the effect of ISO 14001 certification) positively impact accounting performance (e.g., Inoue \& Lee, 2011; Jang et al., 2017; Rodriguez \& Cruz, 2007) and hotel-specific performance (Molina-Azorín et al., 2009; Rodríguez \& Cruz, 2007; Segarra-Oña et al., 2012; de Oliveira et al., 2020; Peiró-Signes et al., 2014), but negatively impact market performance (Dogru \& Sirakaya-Turk, 2016; Ham \& Lee, 2011; Inoue \& Lee, 2011; Singal, 2013). Of the studies reviewed, research on market performance in a hotel context is almost non-existent; nevertheless, mainstream literature suggests that announcing environmental awards positively influences market reactions and investor behavior (Du, 2015; Heras-Saizarbitoria et al., 2020; Nicolau, 2008).

Given that the results from the studies reviewed that specifically examine the relationship between environmental awards and market performance are scant and, in some cases, inconclusive or contradictory, it is difficult to arrive at a consensus on the direction of this relationship. Therefore, we go beyond hospitality research to build on newer work in mainstream literature on corporate environmental management to examine the impact of environmental awards on forward-looking performance metrics, such as market value. We believe that the market will value hotels that announce their environmental awards, since the act reduces information asymmetry (Luffarelli, \& Awaysheh, 2018) and signals that a chain hotel, which consumes significant resources, has made an environmental commitment that may be economically beneficial over time.

\section{THE IMPACT OF ENVIRONMENTAL AWARDS ON MARKET PERFORMANCE}

Scholarly research on the link between corporate environmental management and corporate financial performance has attracted much attention in literature over the past few years. Particularly, research streams have taken either a "cost to be green" or "pay to be green" route to evaluate the impact of environmental awards on firm performance. Empirical studies endorsing the "cost to be green" perspective use neo-classical economic theories to argue that firms often refuse to take on voluntary programs where the benefits do not surpass the accompanying costs (e.g., Welch et al., 2002). In this regard, although certain environmental awards may improve the image of a firm, they do not necessarily translate into superior environmental performance 
(Bansal \& Hunter, 2003) or profit returns due to the significant costs and operating procedures associated with environmental awards (Cañón-de-Francia \& Garcés-Ayerbe, 2009). Essentially, the "cost to be green" perspective argues that implementing various environmental awards can place substantial financial burden on firms (King \& Lenox, 2001) and accordingly, studies supporting this view find that firms' environmental awards (e.g., ISO 14001) negatively affect market performance (Paulraj \& de Jong, 2011; Riaz \& Saeed, 2019).

Studies defending the "it pays to be green" perspective have applied resource-based (Hart \& Dowell, 2011), agency (Aarts \& Vos, 2001), and stakeholder (Parmar et al., 2010) theories to propose a positive impact of environmental awards (e.g., ISO 14001 certification) on market performance based on potential image enhancement, market share gains, and competitive advantages. (Jacobs, Singhal, \& Subramanian, 2010; Heras-Saizarbitoria et al., 2020; Klassen \& Mclaughlin, 1996; Lee, Noh, Choi, \& Rha, 2017; Leonidou et al., 2013; Mellahi et al., 2016). In particular, the stock market's positive reaction could be a result of the perception of environmental awards as a type of strategic philanthropy (Rhou \& Singal, 2020), that can simultaneously increase social welfare and provide internal benefits to a firm (e.g., brand management, reduced energy costs, cost management). For example, general hotel CSR activities were found to positively affect hotel firms' stock value in the China Stock Market (Qiu et al., 2021).

In an attempt to explain the stock market's positive reaction to environmental awards in mainstream literature, scholars have also included the effects of first-time awards and firm assets in their evaluation (Klassen \& Mclaughlin, 1996; Lee et al., 2017), finding that firms with larger assets are generally more profitable and that a firm's first-time announcement of ISO 14001 certification is more valued in the marketplace than are subsequent announcements.

In addition, Testa, Miroshnychenko, Barontini, and Frey (2018) find that understating (brownwashing) or overstating (greenwashing) environmental achievements negatively impact a firm's operating performance and market value. This implies that firms should take a balanced approach to promote the environmental initiatives that they actively engage in. Going beyond these frameworks, Cavero-Rubio and Amorós-Martínez (2020) employ a meta-analysis, longitudinal research design to question "when does it pays to be green?" by examining the link between Spanish hotels' corporate environmental management - corporate financial performance relation during the 2008 financial crisis. They find that, on average, certified hotels withstood the crisis better than non-certified hotels because the certification process positively influenced hotel worker efficiency, asset management, and increased sales. In contrast, these metrics worsened for non-certified hotels during this period.

The present study builds on these arguments by going beyond ISO 14001 certification which has been used in both hospitality and mainstream literature as a proxy for firms' environmental awards and instead evaluate announcements of several industry-specific environmental awards (e.g., Green Key Eco-Rating Program, Green Globe, etc.) on market performance over a period of time (e.g., 1996-2020), an approach that has been overlooked in previous literature.

The objective of using stock performance as a measure of hotel market value is warranted in that the share price reflects a firm's true value by presenting the current value of future profits and instantly adjusts to external factors that could potentially influence the market (Nicolau, 2008), thus filling a gap in hospitality research for an objective measure of the effect of environmental awards on green behavior (Sharma et al., 2020). Given the compelling empirical evidence in the mainstream literature supporting the positive link between environmental 
management and financial performance due to reduced information asymmetries, potential image enhancement, strategic philanthropy, market share gains, and long-term competitive advantages (King et al., 2005; Leonidou et al., 2013; Molina-Azorín et al., 2009; Mellahi et al., 2016; Rhou \& Singal, 2020), we expect an increase in market value following a hotel's environmental awards. Therefore, we propose that:

$H_{1}$. The announcements of a hotel's environmental awards have a positive effect on market value.

\subsection{First environmental award}

Since we expect the market to react positively to a hotel's announcement of its environmental awards, we hypothesize that the impact of its first award on performance is greater than that of subsequent awards received. In line with theories on learning curve effects (Nehrt, 1996, 1998), Christmann (2000) finds that firms who adopt environmental management systems earlier than their competitors gain cost advantages due to process innovation. In particular, Russo (2009) finds strong evidence of a positive link between early certification and environmental performance; the author attributes the favorable ratio of cost to benefits to the perception of improved efficiency in firm procedures from the new certification process. Similarly, Lee et al. (2017) finds that the market's positive response to a firm's first environmental award is observed during the preparation and implementation phase of environmental management, and Klassen and McLaughlin (1996) find that firms' first-time environmental awards have a positive effect on market value compared to subsequent awards, since a firm's first award provides new information to the market, while subsequent awards merely reinforce earlier effects. Therefore, we hypothesize that:

$\mathrm{H}_{2}$ The impact of the first environmental award on performance is greater than that of subsequent awards received.

\subsection{Accumulated awards}

Accumulating multiple certifications is discussed in the literature as a viable firm strategy to expand operational efficiencies (Ferrón-Vílchez \& Darnall, 2016) and improve long-term costsaving initiatives (Llach et al., 2013). Nevertheless, the impact of various combinations of certifications has rarely been studied and requires further investigation (Gianni, Gotzamani, \& Tsiotras, 2017). Intuitively, although investors see investments in environmental practices as a positive strategy, they are aware that there are costs involved (Paulraj \& de Jong, 2011). For example, the initial cost of implementing several environmental awards is significant, thereby potentially reducing a firm's market value (Halkos \& Evangelinos, 2002). This outcome could manifest in a downtrending pattern: investing too much may reduce profitability.

In particular, Paulraj \& de Jong (2011) find that subsequent environmental awards can be perceived as an unnecessary cost. Nevertheless, after a certain number of awards, economies of scale may emerge such that positive effects on market value could be expected. This pattern can be explained through the lens of institutional theory, which purports that when a corporate strategy (e.g., environmental awards) spreads throughout the market and gains legitimacy, it accumulates symbolic value (Tolbert \& Zucker, 1999); thus, the effect of environmental awards is perceived to develop over time from a firm's historical record of efficiency outcomes (Zajac \& Wesphal, 2004). Accordingly, the market value of a hotel is expected to change as new information becomes available to reflect the value of environmental awards over time (Riaz \& Saeed, 2019). Therefore, we hypothesize that:

H3 After an initial decreasing effect of environmental awards, an increasing impact is expected beyond a certain number of awards. 


\section{METHODOLOGY}

The methodology used to test the effect of announcement of environmental awards on hotel market value is the event study method. Considering the assumption of market efficiency, shares prices should reflect all the available information at a specific moment in time. Thus, if the award is perceived to be relevant information, this information should be incorporated into the share price in the way of "abnormal" reactions, i.e., abnormal returns. As the market value is a forward-looking metric of performance, its analysis permits the exploration of shareholders' perceptions of the impact of environmental awards on a hotel's future performance. We detect all the announcements of environmental awards ever made by the major publicly traded hotels in US stock markets by using the Factiva database. The initial number of announcements found is 251. However, after adjusting by available stock data during the period of study (for example, Hilton stopped trading in 2007 and was back in 2013) and controlling for confounding effects (for example, to be conservative we discard announcements that are too close to each other in a 3 -day window), the final sample is 150 announcements. Table 1 shows the descriptive information of these awards distributed across hotels and years.

Table 1. Descriptive statistics of environmental awards by hotel and year

\begin{tabular}{|c|c|c|c|c|c|c|c|c|}
\hline & $\begin{array}{c}\text { Choice } \\
\text { Hotels } \\
\text { International }\end{array}$ & Hilton & Hyatt & $\begin{array}{c}\text { Intercontinental } \\
\text { Hotel }\end{array}$ & Marriott & Starwood & Wyndham & $\begin{array}{c}\text { Total per } \\
\text { year }\end{array}$ \\
\hline 1996 & 0 & 0 & 0 & 0 & 1 & 0 & 0 & 1 \\
\hline 2000 & 0 & 1 & 0 & 0 & 0 & 0 & 0 & 1 \\
\hline 2001 & 0 & 1 & 0 & 0 & 1 & 0 & 0 & 2 \\
\hline 2003 & 0 & 0 & 0 & 0 & 1 & 0 & 0 & 1 \\
\hline 2007 & 0 & 4 & 0 & 0 & 4 & 0 & 0 & 8 \\
\hline 2008 & 0 & 0 & 0 & 0 & 14 & 1 & 2 & 17 \\
\hline 2009 & 0 & 0 & 0 & 3 & 5 & 0 & 0 & 8 \\
\hline 2010 & 0 & 0 & 0 & 1 & 22 & 4 & 1 & 28 \\
\hline 2011 & 0 & 0 & 0 & 2 & 19 & 1 & 0 & 22 \\
\hline 2012 & 1 & 0 & 1 & 1 & 14 & 0 & 0 & 17 \\
\hline 2013 & 0 & 0 & 4 & 0 & 1 & 0 & 1 & 6 \\
\hline 2014 & 0 & 2 & 3 & 2 & 4 & 0 & 2 & 13 \\
\hline 2015 & 1 & 3 & 3 & 1 & 1 & 0 & 1 & 10 \\
\hline 2016 & 0 & 0 & 0 & 0 & 1 & 0 & 0 & 1 \\
\hline 2017 & 1 & 1 & 3 & 1 & 0 & 0 & 0 & 6 \\
\hline 2018 & 0 & 1 & 1 & 0 & 1 & 0 & 1 & 4 \\
\hline 2019 & 0 & 0 & 1 & 0 & 3 & 0 & 0 & 4 \\
\hline 2020 & 0 & 0 & 1 & 0 & 0 & 0 & 0 & 1 \\
\hline $\begin{array}{c}\text { Total per } \\
\text { hotel }\end{array}$ & 3 & 13 & 17 & 11 & 92 & 6 & 8 & 150 \\
\hline
\end{tabular}

Rather than analyzing only the day the award was granted, we examine 3 days around the announcements. It is a usual practice to look at the days around the announcement just in case there is any leakage prior to the official announcement; for this specific case, this is even more relevant as we have observed that firms tend to announce that there is an upcoming outcome 
regarding their application for environmental certificates, with some hotels explicitly making this kind of pre-announcement. Consequently, we use a $(-3,+3)$ event window, which should be long enough to capture any potential leakages (and also potential delays, if any) but not too long to include other announcements that would lead us to further reduce the sample. For each announcement, we estimate the market model for 300 days prior to the announcement:

$$
R_{i t}=\alpha_{i}+\beta_{i} R_{m t}+\varepsilon_{i t}
$$

where $R_{i t}$ is the hotel $i$ 's daily returns on day $t, R_{m t}$ is the returns of the market portfolio, $\alpha_{i}$ is the constant that reflect the returns of hotel $i$ independent of the market's trends, $\beta_{i}$ is the firm's sensitivity to the market, and $\varepsilon_{i t}$ is the error term.

While the previous expression is the basic version of the market model, to better reflect the returns, we estimate the four-factor model that consists of the Fama-French three-factor model (Fama and French, 1993) plus the momentum factor proposed by Carhart (1997):

$$
R_{i t}=\alpha_{i}+\beta_{i} R_{m t}+s_{i} S M B_{t}+h_{i} H M L_{t}+u_{i} U M D_{t}+\varepsilon_{i t}
$$

where $S M B_{t}$ is the size factor defined as the "mean return on small market-capitalization portfolios minus the mean return on three large market-capitalization portfolios"; $H M L_{t}$ is the book-to-market premium defined as the "mean return on two high book-to-market equity portfolios minus the mean return on two low book-to-market equity portfolios"; and $U M D_{t}$ is the premium on winners vs losers defined as the "mean return on two high prior return portfolios minus the mean return on two low prior returns portfolios." The parameters $s_{i}, h_{i}$ and $u_{i}$ capture the effect of these variables on the firm's return.

The following equation estimates any abnormal returns derived from environmental awards:

$$
A R_{i t}=R_{i t}-\left(a_{i}+b_{i} R_{m t}\right)
$$

where $a_{i}$ and $b_{i}$ are the coefficients estimated for a period of a 300 days before the event. To estimate these coefficients, we use the autoregressive conditional heteroskedasticity model (GARCH), whose conditional variance $h_{i t}$ is $h_{i t}=c_{i}+\lambda_{i} \varepsilon_{i t-1}^{2}+\gamma_{i} h_{i t-1}$, so that the previous error term is defined as $\varepsilon_{i t}=h_{i t}^{1 / 2} \eta_{i t}$, where $\varepsilon_{i t} / \varepsilon_{i t-1}, \varepsilon_{i t-2, \ldots \sim \mathrm{N}}\left(0, h_{i t}\right)$, and $\eta_{i t}$ is i.i.d. with $\mathrm{E}\left(\eta_{i t}\right)=0$ and $\mathrm{E}\left(\eta_{i t}^{2}\right)=1$. The coefficients $c_{i}, \lambda_{i}$, and $\gamma_{i}$ are to be estimated. To analyze the significance of the abnormal returns, we use the cross-sectional test (Pilotte, 1992), expressed as

$$
t=\frac{\frac{1}{N} \sum_{i=1}^{N} A R_{i 0}}{\sqrt{\frac{1}{N(N-1)} \sum_{i=1}^{N}\left(A R_{i 0}-\sum_{i=1}^{N} \frac{A R_{i 0}}{N}\right)^{2}}}
$$

where $N$ is the number of announcements and $A R_{i 0}$ is the abnormal return on day 0 or the event day (the same formula is applied to each of the seven days in the $(-3,+3)$ window).

To detect the potential existence of long-term abnormal returns (for periods of one year or more), in line with Sorescu et al. (2007), we also estimate buy-and-hold abnormal returns $\left(B_{\left.H A R_{i t}\right)}\right.$ defined as

$$
B H A R_{i t}=\prod_{t=1}^{T}\left(1+R_{i t}\right)-\prod_{t=1}^{T}\left(1+R_{m t}\right)
$$

Also, we use the calendar-time portfolio approach (also known as the Jensen's alpha approach) to examine long-term abnormal returns. This approach creates a portfolio with the firms experiencing the event and then analyzes whether this portfolio generates abnormal returns during a specific period of time (Jaffe, 1974; Mandelker, 1974). 
Once we estimate the abnormal returns, a regression is estimated via ordinary least squares, where the dependent variable is formed by these abnormal returns and the explanatory variables are: i) first-time award (First), measured by a dummy variables that take value 1 if the environmental award is the first one and 0 otherwise; ii) cumulative awards ( $\mathrm{Cum})$ and the squared cumulative $\left(\mathrm{Cum}^{2}\right)$, measured by the number of environmental awards obtained by the hotel until award $i$; and iii) two control variables, "size" - measured by the assets of the hoteland "years" - measured by a dummy variable that takes value 1 when the award announcement occurs in year $j$ (where year 1996 is the reference base to estimate the parameters). The resulting model is as follows:

$$
A R_{i}=\theta_{1}+\theta_{2} \text { First }_{i}+\theta_{3} \text { Cum }_{i}+\theta_{4} \text { Cum }^{2}+\gamma \log \left(\text { size }_{i}\right)+\sum_{j=1}^{J} \delta_{j} \text { Year }_{i j}+\mu_{i}
$$

where the parameters $\theta, \gamma$ and $\delta$ represent the influence of the aforementioned variables on the abnormal returns; and $\mu_{i}$ is the error term.

\section{FINDINGS}

Table 3 shows the effect of environmental awards on hotel market value. The results indicate that, on average, announcements of environmental awards generate positive abnormal returns two days before the official announcement. This result is obtained by the market model as well as the Fama-French-Carhart four-factor model. This anticipation is not surprising because, apart from the potential leakage that might occur, hotels are interested in announcing that an upcoming assessment is coming. To be specific, the average impact of these awards on a hotel's market value is $0.24 \%$ (market model) and $0.23 \%$ (Fama-French-Carhart four-factor model). This result supports hypothesis 1 that the announcements of a hotel's environmental awards have a positive effect on market value, in line with Jacobs et al. (2010), Klassen and Mclaughlin (1996) and Lee et al. (2017). It seems that those actions aiming at reducing any potential negative harm in the environment are perceived to enhance the market value of hotels.

Table 3. Effect of environmental awards on hotel's market value

\begin{tabular}{c|cc|cc}
\hline \hline & \multicolumn{2}{|c|}{ Market model } & \multicolumn{2}{c}{ Fama-French-Carhart four-factor model } \\
\hline Day & $\begin{array}{c}\text { Abnormal } \\
\text { returns }\end{array}$ & Cross-sectional test & Abnormal returns & Cross-sectional test \\
\hline-3 & 0.0006 & 0.549 & 0.00005 & 0.048 \\
-2 & 0.0024 & $1.963 \mathrm{a}$ & 0.0023 & $1.977 \mathrm{a}$ \\
-1 & -0.0006 & -0.469 & -0.0008 & -0.673 \\
0 & 0.0005 & 0.438 & 0.004 & 0.342 \\
1 & -0.0011 & -1.041 & -0.0012 & -1.115 \\
2 & -0.0013 & -1.133 & -0.0017 & -1.625 \\
3 & 0.0006 & 0.512 & 0.0009 & 0.769 \\
\hline
\end{tabular}

$$
\mathrm{a}=\mathrm{prob}<5 \%
$$

Regarding long-term abnormal returns, the analysis of buy-and-hold returns (BHAR) finds that after one year, not significant returns are found (Average abnormal returns $=0.0009$; $t_{\text {heteroskedasticity-consistent }}=0.23$ ). The calendar-time portfolio approach confirms this absence of significance (Cumulated abnormal returns $=-0.003 ; \mathrm{t}=-1.38$ ). The fact that no long-term abnormal returns are detected means that the effect of environmental awards is totally impounded into the market value at the time of the event. Thus, while we cannot detect that there is a persistent long- 
run effect on stock prices, we do observe a short-run effect of environmental award on stock prices.

After detecting that environmental awards bring about abnormal returns (in the shortterm), we test, through several regression models, the effects of first-time awards and the cumulative impacts (see Table 3 ).

Table 3. Effects of first-time awards and cumulative impact

\begin{tabular}{lcc}
\hline Key variables & Coefficient & Std. Error \\
First-time award & $0.0354 \mathrm{a}$ & 0.0175 \\
Cumulative & $-0.0006 \mathrm{a}$ & 0.0003 \\
Cumulative $^{2}$ & $0.000005 \mathrm{~b}$ & 0.000002 \\
Control variables & & \\
Size & $0.0050 \mathrm{a}$ & 0.0024 \\
Year 2000 & 0.0054 & 0.0182 \\
Year 2001 & $0.0327 \mathrm{~b}$ & 0.0185 \\
Year 2007 & $0.0295 \mathrm{~b}$ & 0.0178 \\
Year 2008 & 0.0300 & 0.0188 \\
Year 2009 & $0.0442 \mathrm{a}$ & 0.0176 \\
Year 2010 & $0.0354 \mathrm{~b}$ & 0.0183 \\
Year 2011 & $0.0363 \mathrm{~b}$ & 0.0184 \\
Year 2012 & $0.0338 \mathrm{~b}$ & 0.0179 \\
Year 2013 & $0.0311 \mathrm{~b}$ & 0.0181 \\
Year 2014 & $0.0312 \mathrm{~b}$ & 0.0178 \\
Year 2015 & 0.0283 & 0.0180 \\
Year 2016 & $0.0439 \mathrm{a}$ & 0.0180 \\
Year 2017 & 0.0293 & 0.0189 \\
Year 2018 & 0.0288 & 0.0186 \\
Year 2019 & 0.0273 & 0.0182 \\
Year 2020 & -0.0103 & 0.0179 \\
Constant & $-0.0689 \mathrm{a}$ & 0.0304 \\
\hline R-squared & 0.3755 & \\
F-statistic & $3.8780 \mathrm{a}$ & \\
\hline & $\mathrm{a}=$ prob $<5 \% ; \mathrm{b}=\mathrm{prob}<10 \%$ \\
\hline
\end{tabular}

Regarding the effect of first-time environmental awards, a positve and significant coefficient is obtained, in line with Klassen and Mclaughlin (1996), which supports hypothesis 2 that the impact of the first environmental award on performance is greater than that of subsequent awards received. It seems that the market regards the start of this new "green" strategy initiated by the hotel as a positive action. As for the effect of cumulated environmental awards, a negative and significant effect is found for the variable "Cumulative" and a positive and significant parameter is observed for "Cumulative" ${ }^{2}$, thereby bringing about a U-shaped effect. Graph 1 shows this U-shaped effect with a positive effect over the whole range. These results support hypothesis 3 that, after an initial decreasing effect of environmental awards, an 
increasing impact is expected past a certain number of awards. This result is in line with the idea that there is a decreasing effect at first (because of the potential costs involved at the beginning) and, after a certain number of awards, once the firm obtains economies of scale and shareholders become aware of the internal and external benefits of environmental certification, there is an increasing effect.

Graph 1. Effect of cumulative environmental awards

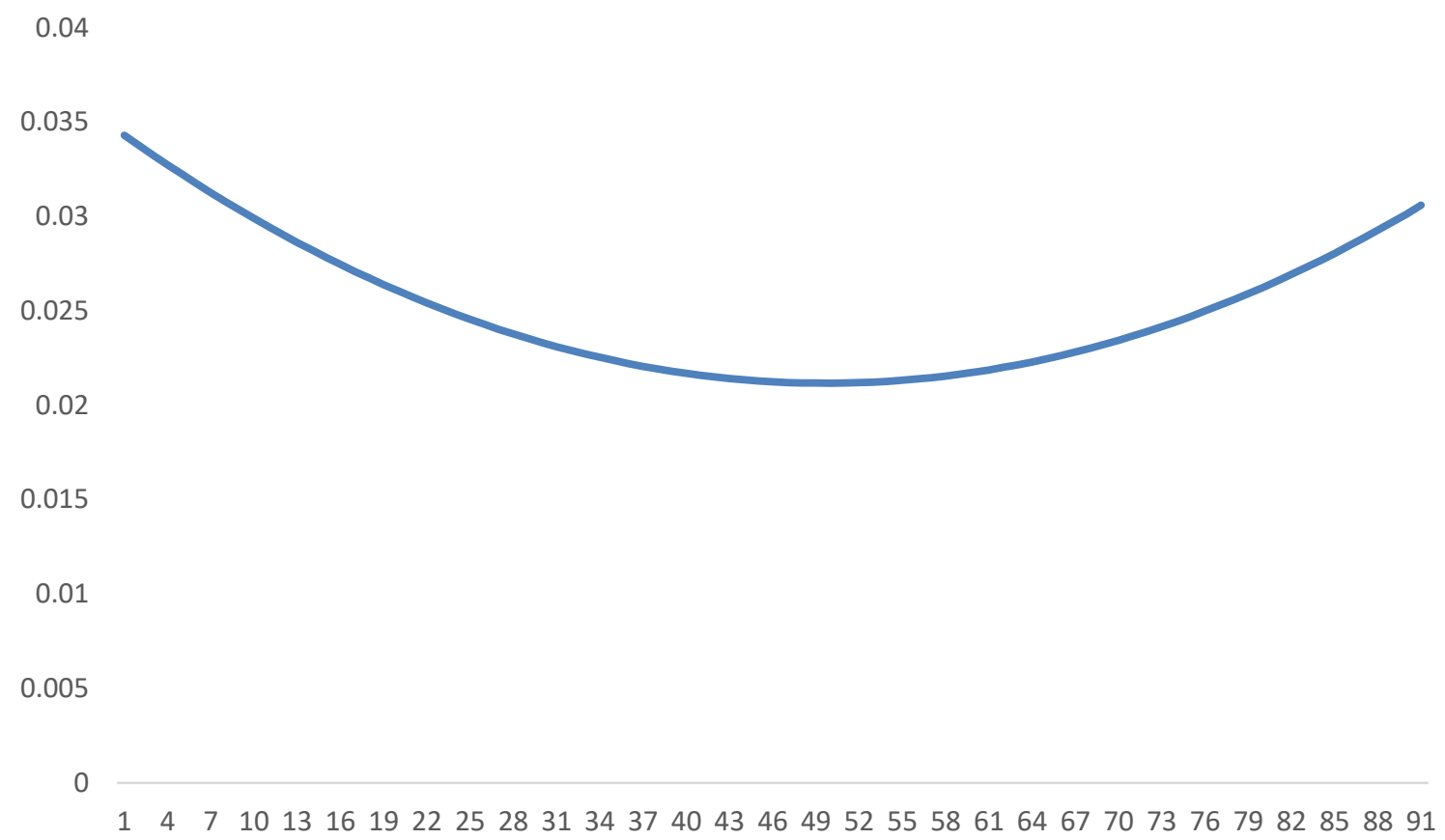

As for the control variables, the hotel's size has a positive and significant parameter, suggesting that the greater the size of the company, the greater the impact of environmental awards. This result is in line with the literature (Segarra-Ona et al., 2012) and can be explained by the fact that, although implementing environmental management systems can be very costly for organizations (King \& Lenox, 2001), chain hotels are in a better financial position to cover these costs compared to smaller independent hotels due to economies of scale. Typically, chain hotels have greater resources and are more capable of cost distribution. Moreover, large companies usually have previous experience regarding certification processes and can effectively transfer that knowledge to other properties at a lower cost (King \& Lenox, 2001).

Regarding the year of the announcements, we obtain significant and positive parameters in years 2001, 2007, 2009, 2010, 2011, 2012, 2013, 2014 and 2016 (compared to 1996). While explaining what happens in every year is beyond the scope of this article, it is surprising that most of the significant parameters appear during and just after the years of the Great Recession, as if hotels increased their concern about the environment despite the limited resources available at the time and shareholders looked those actions positively. Certainly, the literature supports the view that periods of financial crisis are a contingent factor that significantly influences the relationship between environmental management and performance (Cavero-Rubio \& AmorósMartinez, 2020; Gallego-Álvarez et al., 2014). Although there are cases where hotels may have decreased eco-innovative measures during the 2008 economic crisis, García-Pozo et al. (2016) 
found an increase in the number of hotels implementing or developing strategic plans to overcome the crisis.

In particular, Cavero-Rubio and Amoros-Martinez (2020) found that, on average, certified hotels were able to withstand the crisis better than non-certified hotels since their financial performance was enhanced by the positive influence of worker efficiency and asset management, as well as the increase in sales. These metrics worsened for non-certified hotels during this period of economic recession. In other words, certification enabled certified hotels to improve their internal processes and operational costs (Chan, 2009). This may explain shareholders' positive perceptions and the positive results we have obtained.

\section{DISCUSSION AND CONCLUSION}

A typical environmental strategy adopted by hospitality firms is to accumulate several environmental awards to quell greenwashing allegations (Karlsson \& Dolnicar, 2016) and improve their operational procedures (e.g., Chong \& Verma, 2013). However, these strategies are insufficient to effectively measure the effects of environmental awards. The present research goes beyond the typical assessment of ISO 14001 awards, to apply an event study methodology to detect all announcements of environmental awards ever made by the major publicly traded hotels in U.S. stock market by using the Factiva database. The results show that the announcements of environmental awards lead to short-term increases in the market value of hotels; in fact, no long-term abnormal returns are identified, thus no persistent impacts are observed, which means that these alluded increases only happen around the time of the announcement; increases that are especially high for first-time awards, and gradually for subsequent accumulated awards as observed through a U-shaped effect.

This study has relevant theoretical and practical implications. With regard to academic contributions, this study responds to Sharma, Chen and Liu's (2020) review study requesting objective measures of the effect of environmental awards on green behavior. Shifting from prominent theories on corporate social responsibility, corporate sustainability, and stakeholder theory that focuses on what sustainability means to corporations (Chang et al., 2017), this study goes beyond these frameworks to introduce evolving theories that shows how hotels can use environmental certification to attain a sustainable business model. Particularly, the proposed relationships are explained through institutional theories and economic theories on learning curve effects that are novel to this research context.

Although a broad range of hospitality research has taken a rear-view mirror perspective to focus on the relationship between environmental awards and backward-looking financial performance metrics for hotels (for e.g., Chong \& Verma, 2013; Peiró-Signes et al., 2014), these studies overlook the effect that environmental awards have on forward-looking performance metrics, such as market value. Adding this variable complement and extends environmental management research in a hospitality context by introducing a forward-looking metric of performance that presents the current value of future profits to be obtained from hotels that attain various environmental awards. Going beyond the "cost to be green" -"pay to be green" theoretical framework, this study adds several explanatory variables to enhance our finding of a positive effect of environmental awards on the market value of hotels. In particular, our study validates and expands the current literature by being the first to test the effects of first-time and cumulative environmental awards of hotels performing in the U.S. stock market. We consider control variables as guided by the literature, such as hotel size (to take the potential resources into account) and year of announcement (to control for exogeneous factors such as the 2008 recession). Additionally, instead of testing only the effect of ISO 14001 certification as 
previously done in the literature, we go further and include hotel industry-specific awards such as WTTC, Green Key Eco Rating, Green Seal, and others that are used by the top U.S.- hotel chains.

Regarding practical contributions, the findings of this research are beneficial to hotel managers. Considering consumers' growing interest in environmental products and services (Rahman et al., 2015) and chain hotels' goals to increase visibility and improve their corporate images (Bonilla Priego et al., 2011; Tsai et al., 2010), this study satisfies these criteria by applying a market-driven variable that permits the objective investigation of the link between environmental awards and hotels' future performance. The findings show that the market reacts positively to the announcement of environmental awards even before the official announcement, which means that financial returns are possible even during the preparation phase for environmental awards. Therefore, implementing environmental awards appears to be a profitable environmental strategy for hotel managers. This positive development can hopefully encourage hotels to upgrade existing low-cost practices such as towel reuse programs to more reputable environmental awards as the latter have been found to be favored by the market.

The findings also suggest that first-time awards are perceived by the market as more profitable than subsequent awards. This is because first-time awards provide new information to the market, while subsequent awards merely reinforce earlier effects (Klassen \& McLaughlin, 1996). The positive effect from first-time awards can also be explained by theories on learning curve effects (Nehrt, 1996, 1998) to show that the market rewards hotels that take a proactive approach to implement novel environmental strategies, thereby paving the way for other businesses to follow suit through process innovation. Therefore, hotel managers are advised to act swiftly with plans to implement environmental awards for the first time at their properties, since this is perceived by the market as a positive action. This action could signal to the market that these hotels are truly dedicated to reducing their carbon footprint above and beyond the advantage of financial gain.

Accordingly, environmental awards can complement Sun, Cadarso, and Driml's (2020) environmentally extended input-output model for tourism businesses to provide relevance, completeness, and transparency, since the process allows tourism business to track their carbon emission. Particularly, by implementing environmental awards, managers would be able to reduce risks from impending regulatory measures, while simultaneously increase opportunities that will reduce their operation costs, reduce carbon footprint and meet the growing demand for environmentally friendly products and services.

With regard to accumulated awards, while the market initially reacts positively to accumulated environmental awards, this effect decreases - possibly due to the significant implementation costs involved - (Paulraj \& de Jong, 2011), then recovers after a certain number of awards are obtained. This indicates that although the investment in more than one environmental award can be perceived as "an unnecessary cost" (Paulraj \& de Jong, 2011), once this strategy offers proof that environmental awards enable hotels to be more efficient (Zajac \& Wesphal, 2004) the addition of new awards further enhances the market value of hotels.

This is encouraging for industry practitioners in that it shows the long-term financial benefits of accumulating environmental awards. Therefore, hotels are advised to share the benefits they gain from implementing environmental awards. Although it is not out of the ordinary for some hotels to limit information about environmental awards (Heras-Saizarbitoria et al., 2020), often arguing that they are not recognized by potential customers (Geerts, 2014), the findings of this study contradict these claims. The market not only recognizes the environmental 
awards promoted by hotel firms, but it also responds favorably. Indeed, this study highlights the importance of assessing the effects of environmental awards from multiple stakeholder perspectives to separate perception from behavior, thus reducing the ongoing awareness behavior gap in environmental management research.

The study also finds that hotel size and year of the announcement of an environmental award are influential variables to consider. Since chain hotels are predominantly known for their size and global reach, this makes them an ideal context in which to assess the effects of environmental awards. Particularly, chain hotels can extend learning curve effects from properties located in Europe that are leading the way in environmental reporting (Hsieh, 2012), and apply these processes to other regions such as Asia or North America, which have only recently gained interest in environmental management. Interestingly, investing in environmental awards does not seem to be detrimental to hotel market value following periods of recession, as shown by the positive findings particularly after the 2008 financial crisis. Even if by extrapolation, with the entire world currently plunged into the global pandemic caused by COVID-19 that has forced several hotel chains to lay off hospitality workers and close their businesses, it is encouraging to know that environmental awards can help enhance engagement as consumers are expected to grow more supportive of businesses that take action to reduce their environmental harm on the planet (Peiró-Signes et al., 2014).

Some limitations of this study are to be taken into consideration, which in turn may serve to propose future lines of research. Although our sample is comprised of 150 announcements, they come from only the top U.S. hotel chains trading on the stock market. Thus, future studies can use a comprehensive list of hotels around the world and filter this list based on environmental certified versus non-certified properties to make a comparison of their financial performance. Related to this limitation, note that as the hotel companies in the sample are publicly traded, the findings regarding the effects of first-time awards and their accumulation should be corroborated by a sample of hotels that are not publicly traded. Finally, future research could also carry out segmentation analysis to identify how the various segments in the chain hotels are impacted by environmental awards; segments that can be defined not only according to the traditional business vs leisure distinction, but also to psychographics such as attitudes (Passafaro, 2020), to more operational aspects such as the anticipation of the reservation (Campos-Soria et al., 2020), or to more comprehensive criteria such as "sustainable consumer types" (Holmes et al., 2021). 


\section{REFERENCES}

Aarts, F. M., \& Vos, E. (2001). The impact of ISO registration on New Zealand firms'

Bansal, P., \& Hunter, T. (2003). Strategic explanations for the early adoption of ISO 14001. Journal of Business Ethics, 46(3), 289-299.

Bohdanowicz, P. (2005). European hoteliers' environmental attitudes: Greening the business. Cornell Hotel and Restaurant Administration Quarterly, 46(2), 188-204.

Bojanic, D. C., \& Warnick, R. B. (2020). The relationship between a country's level of tourism and environmental performance. Journal of Travel Research, 59(2), 220-230.

Bonilla Priego, M. J., Najera, J. J., \& Font, X. (2011). Environmental management decisionmaking in certified hotels. Journal of Sustainable Tourism, (3), 361-381.

Bratt, C., Hallstedt, S., Robèrt, K. H., Broman, G., \& Oldmark, J. (2011). Assessment of ecolabelling criteria development from a strategic sustainability perspective. Journal of Cleaner Production, 19(14), 1631-1638.

Buckley, R. (2001). Major issues in tourism ecolabelling. In: Font, X., Buckley, R.(Eds.) Tourism ecolabelling: certification and promotion of sustainable management. CABI Publishing, Wallingford, pp. 19-26.

Campos-Soria, J. A., Núñez-Carrasco, J. A., \& García-Pozo, A. (2020). Environmental Concern and Destination Choices of Tourists: Exploring the Underpinnings of Country Heterogeneity. Journal of Travel Research, 0047287520933686.

Cañón-de-Francia, J., \& Garcés-Ayerbe, C. (2009). ISO 14001 environmental certification: a sign valued by the market? Environmental and Resource Economics, 44(2), 245-262.

Carhart, M. M. (1997). On persistence in mutual fund performance. The Journal of finance, 52(1), 57-82.

Cavero-Rubio, J. A., \& Amorós-Martínez, A. (2020). Environmental certification and Spanish hotels' performance in the 2008 financial crisis. Journal of Sustainable Tourism, 28(5), 771-796.

Chan, E. S. (2021). Influencing stakeholders to reduce carbon footprints: Hotel managers' perspective. International Journal of Hospitality Management, 94, 102807.

Chan, E. S., \& Wong, S. C. (2006). Motivations for ISO 14001 in the hotel industry. Tourism Management, 27(3), 481-492.

Chan, W. W. (2009). Environmental measures for hotels' environmental management systems. International Journal of Contemporary Hospitality Management, 21(5), 542-560.

Chang, R. D., Zuo, J., Zhao, Z. Y., Zillante, G., Gan, X. L., \& Soebarto, V. (2017). Evolving theories of sustainability and firms: History, future directions and implications for renewable energy research. Renewable and Sustainable Energy Reviews, 72, 48-56.

Chen, Y. S., \& Chang, C. H. (2013). Green wash and green trust: The mediation effects of green consumer confusion and green perceived risk. Journal of Business Ethics, 114(3), 489500.

Chong, H., \& Verma, R. (2013). Hotel sustainability: Financial analysis shines a cautious green light. Cornell Hospitality Report, 13(10), 4-13.

Christmann, P. (2000). Effects of "best practices" of environmental management on cost advantage: The role of complementary assets. Academy of Management Journal, 43(4), 663-680.

Claver-Cortés, E., Pereira-Moliner, J., Molina-Azorín, J.F., \& Tari-Guilló, J. J. (2010). Certificación enc alidad y medio ambiente y su relacion con el rendimiento empresarial evidencia en el sector hotelero espanol (Certification in quality and environment and its 
relationship with business performance: Evidence in the Spanish hotel sector). Papers de Turisme, 47-48, 24-37.

De Grosbois, D. (2012). Corporate social responsibility reporting by the global hotel industry: Commitment, initiatives and performance. International Journal of Hospitality Management, 31(3), 896-905.

de Oliveira, A. C. R., Santos, G. E. D. O., \& Santos Lobo, H. A. (2020). Environmental Attitudes and Tourist Satisfaction in Overloaded Natural Protected Areas. Journal of Travel Research, 0047287520957419.

Dolnicar, S. (2020). Designing for more environmentally friendly tourism. Annals of Tourism Research, 84, 102933.

$\mathrm{Du}, \mathrm{X}$. (2015). How the market values greenwashing? Evidence from China. Journal of Business Ethics, 128(3), 547-574.

Ecolabel Index (n.d.) Ecolabel directory. Retrieved from http://www.ecolabelindex.com

Ertuna, B., Karatas-Ozkan, M., \& Yamak, S. (2019). Diffusion of sustainability and CSR discourse in hospitality industry. International Journal of Contemporary Hospitality Management. 31(8), 2564-2581.

Fama, E. F. (1991). Efficient capital markets: II. The Journal Finance, 46(5), 1575-1617.

Fama, E. F., \& French, K. R. (1993). Common risk factors in the returns on stocks and bonds (pp. 392-449). Journal of Financial Economics, 33, 3-56.

Ferrón-Vilchez, V., \& Darnall, N. (2016). Two are better than one: The link between management systems and business performance. Business Strategy and the Environment, 25(4), 221-240.

Font, X. (2002). Environmental certification in tourism and hospitality: progress, process and prospects. Tourism Management, 23(3), 197-205.

Gallego-Álvarez, I., García-Sánchez, I. M., \& da Silva Vieira, C. (2014). Climate change and financial performance in times of crisis. Business Strategy and the Environment, 23(6), 361-374.

Garcés-Ayerbe, C., Scarpellini, S., Valero-Gil, J., \& Rivera-Torres, P. (2016). Proactive environmental strategy development: From laggard to eco innovative firms. Journal of Organizational Change Management, 29(7), 1118-1134.

García-Pozo, A., Sánchez-Ollero, J. L., \& Ons-Cappa, M. (2016). ECO-innovation and economic crisis: a comparative analysis of environmental good practices and labour productivity in the Spanish hotel industry. Journal of Cleaner Production, 138, 131-138.

Geerts, W. (2014). Environmental certification schemes: Hotel managers' views and perceptions. International Journal of Hospitality Management, 39, 87-96.

Gianni, M., Gotzamani, K., \& Tsiotras, G. (2017). Multiple perspectives on integrated management systems and corporate sustainability performance. Journal of Cleaner Production, 168, 1297-1311.

Gil, M. A., Jiménez, J. B., \& Lorente, J. C. (2001). An analysis of environmental management, organizational context and performance of Spanish hotels. Omega, 29(6), 457-471.

Global Ecolabeling Network (GEN) (2004) Introduction to ecolabeling. Retrieved from https://globalecolabelling.net/assets/Uploads/intro-to-ecolabelling.pdf

Goldstein, K. A., \& Primlani, R. V. (2012). Current trends and opportunities in hotel sustainability. HVS Sustainability Services, 31.

Gupta, A., Dash, S., \& Mishra, A. (2019). All that glitters is not green: Creating trustworthy ecofriendly services at green hotels. Tourism Management, 70, 155-169. 
Hadjikakou, M., Chenoweth, J., \& Miller, G. (2013). Estimating the direct and indirect water use of tourism in the eastern Mediterranean. Journal of Environmental Management, 114, 548-556.

Halkos, G. E., \& Evangelinos, K. I. (2002). Determinants of environmental management systems standards implementation: evidence from Greek industry. Business Strategy and the Environment, 11(6), 360-375.

Ham, S., \& Lee, S. (2011). US restaurant companies' green marketing via company websites: impact on financial performance. Tourism Economics, 17(5), 1055-1069.

Chen, H., Bernard, S., \& Rahman, I. (2019). Greenwashing in hotels: A structural model of trust and behavioral intentions. Journal of Cleaner Production, 206, 326-335.

Hart, S. L., \& Dowell, G. (2011). Invited editorial: A natural-resource-based view of the firm: Fifteen years after. Journal of Management, 37(5), 1464-1479.

Heras-Saizarbitoria, I., Boiral, O., Allur, E., \& García, M. (2020). Communicating environmental management certification: Signaling without signals? Business Strategy and the Environment, 29(2), 422-431.

Hoffman, A. J., \& Bansal, P. (2012). Retrospective, perspective, and prospective: Introduction to the Oxford handbook on business and the natural environment. In The Oxford handbook of business and the natural environment. In P. Bansal \& A. J. Hoffman (Eds.), The Oxford handbook on business and the natural environment (pp. 3-25). Oxford: University Press.

Holmes, M. R., Dodds, R., \& Frochot, I. (2021). At home or abroad, does our behavior change? Examining how everyday behavior influences sustainable travel behavior and tourist clusters. Journal of Travel Research, 0047287519894070.

Hsieh, Y. C. J. (2012). Hotel companies' environmental policies and practices: a content analysis of their web pages. International Journal of Contemporary Hospitality Management, 24 (1)97-121.

Inoue, Y., \& Lee, S. (2011). Effects of different dimensions of corporate social responsibility on corporate financial performance in tourism-related industries. Tourism Management, 32(4), 790-804.

Jacobs, B. W., Singhal, V. R., \& Subramanian, R. (2010). An empirical investigation of environmental performance and the market value of the firm. Journal of Operations Management, 28(5), 430-441.

Jaffe, J., (1974), Special information and insider trading, Journal of Business 47: 411-428.

Jang, Y. J., Zheng, T., \& Bosselman, R. (2017). Top managers' environmental values, leadership, and stakeholder engagement in promoting environmental sustainability in the restaurant industry. International Journal of Hospitality Management, 63, 101-111.

Jauhari, V., \& Manaktola, K. (2007). Exploring consumer attitude and behaviour towards green practices in the lodging industry in India. International Journal of Contemporary Hospitality Management, 19 (5), 364-377.

Kang, K. H., Stein, L., Heo, C. Y., \& Lee, S. (2012). Consumers' willingness to pay for green initiatives of the hotel industry. International Journal of Hospitality Management, 31(2), 564-572.

Karlsson, L., \& Dolnicar, S. (2016). Does eco certification sell tourism services? Evidence from a quasi-experimental observation study in Iceland. Journal of Sustainable Tourism, 24(5), 694-714. 
King, A. A., \& Lenox, M. J. (2001). Who adopts management standards early? an examination of iso 14001 certifications. In Academy of Management Proceedings, 1, A1-A6.

Klassen, R. D., \& McLaughlin, C. P. (1996). The impact of environmental management on firm performance. Management Science, 42(8), 1199-1214.

Lee, J. S., Hsu, L. T., Han, H., \& Kim, Y. (2010). Understanding how consumers view green hotels: how a hotel's green image can influence behavioural intentions. Journal of Sustainable Tourism, 18(7), 901-914.

Lee, S. M., Noh, Y., Choi, D., \& Rha, J. S. (2017). Environmental policy performances for sustainable development: from the perspective of ISO 14001 certification. Corporate Social Responsibility and Environmental Management, 24(2), 108-120.

Lee, Y. C., Hu, J. L., \& Ko, J. F. (2008). The effect of ISO certification on managerial efficiency and financial performance: An empirical study of manufacturing firms. International Journal of Management, 25(1), 166.

Leonidou, L. C., Leonidou, C. N., Fotiadis, T. A., \& Zeriti, A. (2013). Resources and capabilities as drivers of hotel environmental marketing strategy: Implications for competitive advantage and performance. Tourism Management, 35, 94-110.

Lesar, L., Weaver, D., \& Gardiner, S. (2020). From spectrum to multiverse: a new perspective on the diversity of quality control tools for sustainable tourism theory and practice. Journal of Travel Research, 59(3), 424-449.

Llach, J., Perramon, J., del Mar Alonso-Almeida, M., \& Bagur-Femenías, L. (2013). Joint impact of quality and environmental practices on firm performance in small service businesses: An empirical study of restaurants. Journal of Cleaner Production, 44, 96-104.

Luffarelli, J., \& Awaysheh, A. (2018). The impact of indirect corporate social performance signals on firm value: Evidence from an event study. Corporate Social Responsibility and Environmental Management, 25(3), 295-310.

Mandelker, G., (1974), Risk and return: The case of merging firms, Journal of Financial Economics 1: 303-335.

Mellahi, K., Frynas, J. G., Sun, P., \& Siegel, D. (2016). A review of the nonmarket strategy literature: Toward a multi-theoretical integration. Journal of Management, 42(1), 143173.

Mensah, I., \& Blankson, E. J. (2014). Commitment to environmental management in hotels in Accra. International Journal of Hospitality \& Tourism Administration, 15(2), 150-171.

Mkono, M. (2020). Eco-hypocrisy and inauthenticity: Criticisms and confessions of the ecoconscious tourist/traveller. Annals of Tourism Research, 84, 102967.

Molina-Azorín, J. F., Claver-Cortés, E., Pereira-Moliner, J., \& Tarí, J. J. (2009). Environmental practices and firm performance: an empirical analysis in the Spanish hotel industry. Journal of Cleaner Production, 17(5), 516-524.

Murillo-Luna, J. L., Garcés-Ayerbe, C., \& Rivera-Torres, P. (2008). Why do patterns of environmental response differ? A stakeholders pressure approach. Strategic Management Journal, 29(11), 1225-1240.

Mycoo, M. (2006). Sustainable tourism using regulations, market mechanisms and green certification: a case study of Barbados. Journal of Sustainable Tourism, 14(5), 489-511.

Myung, E., Kim, Y. S., \& Barrett, S. (2020). Environmental Management and Performance of Hospitality Firms: Review and Research Agenda. Journal of Quality Assurance in Hospitality \& Tourism, 21(6), 667-689. 
Nehrt, C. (1996). Timing and intensity effects of environmental investments. Strategic Management Journal, 17(7), 535-547.

Nehrt, C. (1998). Maintainability of first mover advantages when environmental regulations differ between countries. Academy of Management Review, 23(1), 77-97.

Nicolau, J.L. (2008). Corporate social responsibility: Worth-creating activities. Annals of Tourism Research, 35(4), 990-1006.

Parguel, B., Benoit-Moreau, F \& Larceneux, F, (2011). How sustainability ratings might deter 'greenwashing': a closer look at ethical corporate communication. Journal of Business Ethics, 102(1), 15-28.

Parmar, B. L., Freeman, R. E., Harrison, J. S., Wicks, A. C., Purnell, L., \& De Colle, S. (2010). Stakeholder theory: The state of the art. Academy of Management Annals, 4(1), 403-445.

Passafaro, P. (2020). Attitudes and tourists' sustainable behavior: An overview of the literature and discussion of some theoretical and methodological issues. Journal of Travel Research, 59(4), 579-601.

Paulraj, A., \& De Jong, P. (2011). The effect of ISO 14001 certification announcements on stock performance. International Journal of Operations \& Production Management, 34(5), 586-609.

Peiró-Signes, A., Segarra-Oña, M. D. V., Verma, R., Mondéjar-Jiménez, J., \& Vargas-Vargas, M. (2014). The impact of environmental certification on hotel guest ratings. Cornell Hospitality Quarterly, 55(1), 40-51. performance: a financial perspective. The TQM Magazine. 13(3), 180-91.

Pilotte, E. (1992). Growth opportunities and the stock price response to new financing, Journal of Business, 65(3), 371-394.

Qiu, S. C., Jiang, J., Liu, X., Chen, M. H., \& Yuan, X. (2021). Can corporate social responsibility protect firm value during the COVID-19 pandemic?. International Journal of Hospitality Management, 93, 102759.

Rahman, I., Park, J., \& Chi, C. G. Q. (2015). Consequences of "greenwashing" Consumers' reactions to hotels' green initiatives. International Journal of Contemporary Hospitality Management, 27(6), 1054-1081.

Rhou, Y., \& Singal, M. (2020). A review of the business case for CSR in the hospitality industry. International Journal of Hospitality Management, 84, 102330.

Riaz, H., \& Saeed, A. (2019). Impact of environmental policy on firm's market performance: The case of ISO 14001. Corporate Social Responsibility and Environmental Management, 27(2), 681-693.

Rico, A., Olcina, J., Baños, C., Garcia, X., \& Sauri, D. (2020). Declining water consumption in the hotel industry of mass tourism resorts: Contrasting evidence for Benidorm, Spain. Current Issues in Tourism, 23(6), 770-783.

Rocha, C. M., \& Fink, J. S. (2017). Attitudes toward attending the 2016 Olympic Games and visiting Brazil after the games. Tourism Management Perspectives, 22, 17-26.

Rodríguez, F. J. G., \& Cruz, Y. D. M. A. (2007). Relation between social-environmental responsibility and performance in hotel firms. International Journal of Hospitality Management, 26(4), 824-839.

Russo, M. V. (2009). Explaining the impact of ISO 14001 on emission performance: a dynamic capabilities perspective on process and learning. Business Strategy and the Environment, 18(5), 307-319. 
Segarra-Oña, M. D. V., Peiró-Signes, Á., Verma, R., \& Miret-Pastor, L. (2012). Does environmental certification help the economic performance of hotels? Evidence from the Spanish hotel industry. Cornell Hospitality Quarterly, 53(3), 242-256.

Sharma, T., Chen, J., \& Liu, W. Y. (2020). Eco-innovation in hospitality research (1998-2018): a systematic review. International Journal of Contemporary Hospitality Management. 32(2), 913-933.

Singal, M. (2013). The link between firm financial performance and investment in sustainability initiatives. Cornell Hospitality Quarterly, 55(1), 19-30.

Smith, V. L., \& Font, X. (2014). Volunteer tourism, greenwashing and understanding responsible marketing using market signalling theory. Journal of Sustainable Tourism, 22(6), 942963.

Sorescu, Alina B., Rajesh K. Chandy, and Jaideep C. Prabhu (2007), "Why Some Acquisitions Do Better than Others: Product Capital as a Driver of Long-Term Stock Returns," Journal of Marketing Research, 44 (1), 57-72.

Stefan, A., \& Paul, L. (2008). Does it pay to be green? A systematic overview. Academy of Management Perspectives, 22(4), 45-62.

Sun, Y. Y., Cadarso, M. A., \& Driml, S. (2020). Tourism carbon footprint inventories: A review of the environmentally extended input-output approach. Annals of Tourism Research, 82, 102928.

Testa, F., Miroshnychenko, I., Barontini, R., \& Frey, M. (2018). Does it pay to be a greenwasher or a brownwasher?. Business Strategy and the Environment, 27(7), 1104-1116.

Tirado, D., Nilsson, W., Deya-Tortella, B., \& Garcia, C. (2019). Implementation of water-saving measures in hotels in Mallorca. Sustainability, 11(23), 6880.

Tolbert, P. S., \& Zucker, L. G. (1999). The institutionalization of institutional theory. Studying Organization. Theory \& Method. London, Thousand Oaks, New Delhi, 169-184.

Tolkach, D. (2021). Sustainable tourism cannot be harmonised. Annals of Tourism Research, 86. 103101.

Tsai, W. H., Hsu, J. L., Chen, C. H., Lin, W. R., \& Chen, S. P. (2010). An integrated approach for selecting corporate social responsibility programs and costs evaluation in the international tourist hotel. International Journal of Hospitality Management, 29(3), 385396.

Welch, E. W., Mori, Y., \& Aoyagi-Usui, M. (2002). Voluntary adoption of ISO 14001 in Japan: mechanisms, stages and effects. Business Strategy and the Environment, 11(1), 43-62.

Yusoff, Y. M., Nejati, M., Kee, D. M. H., \& Amran, A. (2020). Linking green human resource management practices to environmental performance in hotel industry. Global Business Review, 21(3), 663-680.

Zajac, E. J., \& Westphal, J. D. (2004). The social construction of market value: Institutionalization and learning perspectives on stock market reactions. American Sociological Review, 69(3), 433-457. 